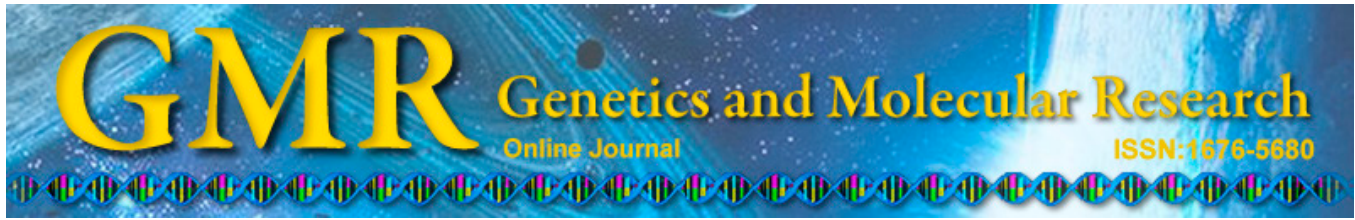

\title{
Genomic lesions and colorectal carcinogenesis: the effects of protein-calorie restriction and inulin supplementation on deficiency statuses
}

\author{
W.B. Cantero ${ }^{1,2}$, N.A. Takahachi ${ }^{3}$, M.O. Mauro ${ }^{4}$, J.R. Pesarini ${ }^{1,2}$, \\ A.P.M. Rabacow ${ }^{1,5}$, A.C.M.B. Antoniolli ${ }^{1,2}$ and R.J. Oliveira ${ }^{1,2,6}$ \\ ${ }^{1}$ Programa de Pós-Graduação em Saúde e Desenvolvimento na Região \\ Centro-Oeste, Faculdade de Medicina, Universidade Federal de Mato Grosso \\ do Sul, Campo Grande, MS, Brasil \\ ${ }^{2}$ Centro de Estudos em Células Tronco, Terapia Celular e Genética Toxicológica- \\ CeTroGen, Hospital Universitário Maria Aparecida Pedrossian, \\ Universidade Federal de Mato Grosso do Sul, Campo Grande, MS, Brasil \\ ${ }^{3}$ Centro de Estudos em Nutrição e Genética Toxicológica, \\ Centro Universitário Filadélfia, Londrina, PR, Brasil \\ ${ }^{4}$ Programa de Doutorado em Biotecnologia e Biodiversidade, \\ Rede Pró Centro-Oeste, Universidade Federal de Mato Grosso do Sul, \\ Campo Grande, MS, Brasil \\ ${ }^{5}$ Instituto de Perícias Científicas - Exames de DNA LTDA, Campo Grande, \\ MS, Brasil \\ ${ }^{6}$ Programa de Mestrado em Farmácia, Centro de Ciências Biológicas e da Saúde, \\ Universidade Federal de Mato Grosso do Sul, Campo Grande, MS, Brasil \\ Corresponding author: R.J. Oliveira \\ E-mail: rodrigo.oliveira@ufms.br
}

Genet. Mol. Res. 14 (1): 2422-2435 (2015)

Received August 11, 2014

Accepted October 8, 2014

Published March 27, 2015

DOI http://dx.doi.org/10.4238/2015.March.27.27

ABSTRACT. The present study investigated the effects of restricting protein and calories and supplementation of inulin, a fiber comprising a linear type of polydisperse carbohydrates composed primarily of 
fructil-fructose bonds $(\beta-(2 \rightarrow 1)$, on the deficiency statuses of animals in which genomic lesion development and colorectal carcinogenesis had been induced. This experiment involved adult male Swiss mice $(\mathrm{N}=11$ /group). The experimental groups were as follows: Negative Control (vehicle), Positive Control, 1,2-dimethylhydrazine (DMH), Inulin, and Associate. DMH, which promoted colorectal cancer, was administered intraperitoneally in $420-\mathrm{mg} / \mathrm{kg}$ body weight (bw) doses during a 2-week period; inulin was administered orally at a daily dose of $50 \mathrm{mg} / \mathrm{kg}$ bw. Each group was bifurcated; half of each group was fed a normal protein diet and the other half was fed a low-protein diet. The results indicated that a correlation existed between malnutrition and an increased frequency of genomic lesions but that malnutrition did not predispose animals to colorectal cancer development. Inulin exhibited genotoxic activity, which requires further investigation, and low antigenotoxic activity. Moreover, inulin reduced the levels of intestinal carcinogenesis biomarkers in both malnourished and healthy animals. These data suggest that inulin holds therapeutic potential and is a strong candidate for inclusion among the functional foods used for cancer prevention in both properly nourished and malnourished individuals.

Key words: Malnourished; Mice; Genotoxic; Protein-calorie restriction

\section{INTRODUCTION}

In developed countries, colorectal cancer is among the most frequent causes of death in individuals who consume diets with high levels of saturated fat and protein and low levels of vegetables, fruits, leafy greens, and fiber. Therefore, it is believed that reducing the intake of animal proteins and fats will reduce colorectal tumor development (Mauro et al., 2013).

The Brazilian population is currently undergoing a nutritional transition; approximately two-thirds of individuals have transitioned from a state of malnutrition to a state of overweight and/or obesity (Lima and Navarro, 2014). This transition is consequent to socioeconomic and lifestyle changes, physical inactivity, and inappropriate caloric food intake (Ferreira et al., 2005). However, several parts of the world, including northeastern Brazil, still contain severely malnourished individuals (protein-calorie malnutrition) who represent an important public health issue (Ribeiro et al., 2014).

According to Silva et al. (2011), there are no sufficient records to conclude whether or how nutritional deficiency can cause cancer or predispose individuals to cancer. The experimental data are also insufficient to correlate malnutrition and chemical carcinogenesis. However, Silva et al. (2011) reported that malnutrition caused by meal feeding did not correlate with the development of aberrant crypt foci (ACF), an important biomarker of colorectal cancer.

Studies have demonstrated that diets that induce and promote the proliferation and maintenance of intestinal microbiota can improve the quality of life and prevent chronic diseases such as cancer and/or the development of cancer biomarkers. Diets with these characteristics are generally rich in pre- and probiotics (Burns and Rowland, 2004; Mauro et al., 2013; Pesarini et al., 2013). 
According to Roberfroid (2002), prebiotic foods beneficially modulate intestinal microflora by stimulating the selective growth and/or activity of a limited number of colonic bacteria such as lactobacilli and bifidobacteria. The oligosaccharide inulin is a possible component of a healthy diet and may be considered a functional prebiotic food, as it interferes beneficially in different physiological and biochemical processes in humans, thereby promoting improved health and a reduced risk of disease (Kaur and Grupta, 2002). This fructan has been further described as capable of reducing the tumor-promoting and mutagenic activities of the xenobiotics present in the daily diet of the population (ANVISA, 2006) in addition to modulating genetic and cytological factors in the colon that prevent or reduce genetic lesions and malignancy formation (Pool-Zobel et al., 2002; Mauro et al., 2013).

Based on the above background, the present study assessed the effects of proteincalorie restriction and inulin supplementation on the deficiency statuses of animals in which genomic lesion development and colorectal carcinogenesis had been induced.

\section{MATERIAL AND METHODS}

\section{Chemical agents}

\section{1,2-Dimethylhydrazine}

The chemical agent 1,2-dimethylhydrazine (DMH, CAS No. 306-37-6; Sigma-Aldrich, St. Louis, MO, USA) was diluted in an aqueous ethylenediaminetetraacetic acid (EDTA; $0.37 \mathrm{mg} / \mathrm{mL}$ ) solution to a concentration of $20 \mathrm{mg} / \mathrm{kg}$ body weight ( $\mathrm{bw}$ ) and administered to the animals intraperitoneally ( $i p$ ) twice weekly for 2 weeks (Mauro et al., 2013).

\section{Inulin}

The functional food inulin was donated by ORAFTI (Tienen, Belgium). Inulin was diluted in distilled water and administered orally ( $\mathrm{po}$ ) at a dose of $50 \mathrm{mg} / \mathrm{kg}(\mathrm{bw})$ according to Mauro et al. (2013).

\section{Diets}

The first lot of animals was fed a normal protein/commercial diet (NPD; Nuvital, Colombo, PR, Brazil) and water ad libitum. The second lot was fed a low-protein diet (LPD) and water ad libitum. The LPD was prepared at Centro de Estudos em Nutrição e Genética Toxicológica (CENUGEN) of Centro Universitário Filadéfia (UniFil).

The basic regional diet formulation as described by Teodósio et al. (1990) and Ferreira et al. (2005) was based on dietary surveys that detected (per $100 \mathrm{~g}$ ) the presence of 18.3 $\mathrm{g}$ brown beans, $64.8 \mathrm{~g}$ cassava flour, $4.1 \mathrm{~g}$ jerked beef, and $12.8 \mathrm{~g}$ sweet potato. The chemical analysis indicated a composition of $7.8 \%$ protein, $73.2 \%$ carbohydrate, $1.5 \%$ fat, $7.2 \%$ fiber, $1.3 \%$ ash, and $9.0 \%$ moisture. This diet was also chosen because of its ability to induce in rats a deficiency status similar to marasmus in humans.

To prepare the LPD, the sweet potato, jerked beef, and beans were cooked, ground, and mixed with cassava flour. Water was added, and the mixture was subsequently pelletized. The pellets were placed in disposable containers and frozen $\left(-4^{\circ} \mathrm{C}\right)$ and were thawed only 
when supplementation was offered to the animals.

In a pilot study using mice (data not shown), supplementation with this diet produced results similar to those reported by Ferreira et al. (2005) with respect to weight gain in rats.

\section{Animals}

Eight experimental groups of 11 animals each were used. The animals were male Swiss mice of reproductive age (60 days) and were obtained from CENUGEN located at Unifil, Londrina, Paraná State. The animals were kept in polypropylene boxes lined with wood shavings. The temperature, light, and humidity were maintained at $22 \pm 2^{\circ} \mathrm{C}$, a 12 -h photoperiod ( $12 \mathrm{~h}$ each of light and dark), and $55 \pm 10 \%$, respectively. The experiment was conducted according to the guidelines of the Universal Declaration of Animal Rights and approved by the Ethics Committee on the Use of Animals of Universidade Estadual de Londrina (Protocol No. 240/2009).

\section{Experimental design}

The animals were treated for 120 days according to the protocols of Mauro et al. (2013) and Pesarini et al. (2013), with modifications. The experimental groups are described below.

\section{Lot 1 - Animals supplemented with an NPD}

In the Negative Control Group (EDTA NPD), the animals were fed a commercial NPD throughout the experimental period; the EDTA solution was administered ip $(0.1 \mathrm{~mL} / 10$ $\mathrm{g}$ bw) twice weekly during weeks 4 and 5 and distilled water was also administered $p o(0.1$ $\mathrm{mL} / 10 \mathrm{~g} \mathrm{bw}$ ) throughout the experimental period. In the Positive Control Group (DMH NPD), the animals underwent the same protocol described above for the EDTA NPD group, but the EDTA solution was replaced with the DMH solution at a dose of $20 \mathrm{mg} / \mathrm{kg}$ bw $i p$. In the Inulin NPD Group, the animals underwent the same protocol described for the EDTA NPD group, but distilled water was replaced with an inulin solution administered $p o$ at a dose of $50 \mathrm{mg} / \mathrm{kg}$ bw. In the Associate NPD Group, the animals underwent the same protocol described for the DMH NPD group, but the DMH solution was replaced with an inulin solution administered po at a concentration of $50 \mathrm{mg} / \mathrm{kg}$ bw.

To evaluate genotoxicity, peripheral blood was collected $24 \mathrm{~h}$ after the last ip administration of either EDTA or DMH. On experimental day 120, the animals were euthanized by cervical dislocation, and their colons and recta were collected for analysis.

\section{Lot 2 - Animals supplemented with an LPD}

The same groups and protocols described above were also performed for Lot 2. However, the NPD was replaced by an LPD for 28 days prior to the administration of the first po dose of inulin or distilled water. The groups in Lot 2 were designated as Negative Control (EDTA LPD), Positive Control (DMH LPD), Inulin LPD, and Associate LPD.

In a pilot experiment (data not shown), a 40-day period of low-protein supplementation caused the death of $40 \%$ of the animals. Based on these data, a 28 -day depletion period (period of LPD supplementation) followed by a 92-day repletion period (NPD supplementa- 
tion) was established in the present study. Therefore, ACF were induced via DMH administration when the animals were in a state of severe malnutrition; subsequently, the animals were again fed the NPD.

\section{Biological assays}

\section{Comet assay}

The comet assay was performed according to Singh et al. (1988), with modifications. To mount the slides, $20 \mu \mathrm{L}$ peripheral blood collected $24 \mathrm{~h}$ after the last dose of DMH or EDTA was deposited with $120 \mu \mathrm{L}$ LPM agarose $(1.5 \%)$ at $37^{\circ} \mathrm{C}$ on a slide pre-coated with standard agarose (5\%). The slides were covered with coverslips and refrigerated at $4^{\circ} \mathrm{C}$ for 20 minutes. After removing the coverslips, the slides were immersed in freshly prepared lysis solution comprising $89.0 \mathrm{~mL}$ stock lysis solution [2.5 M NaCl, 100.0 mM EDTA, $10.0 \mathrm{mM}$ Tris, $\mathrm{pH} 10.0$ (adjusted with solid $\mathrm{NaOH}$ ), $890.0 \mathrm{~mL}$ distilled water], $1.0 \mathrm{~mL}$ Triton X-100 (Merck, Readington Township, NJ, USA), and $10.0 \mathrm{~mL}$ DMSO. The lysis step occurred for 1 $\mathrm{h}$ at $4^{\circ} \mathrm{C}$ under protection from light. Subsequently, the slides were placed in an electrophoresis chamber in $\mathrm{pH}>13.0$ buffer $\left(300.0 \mathrm{mM} \mathrm{NaOH}\right.$ and $1.0 \mathrm{mM}$ EDTA) at $4^{\circ} \mathrm{C}$ for $20 \mathrm{~min}$ for DNA denaturation. Electrophoresis was performed at $25.0 \mathrm{~V}$ and $300.0 \mathrm{~mA}(1.25 \mathrm{~V} / \mathrm{cm})$. Subsequently, the slides were neutralized with $\mathrm{pH} 7.5$ buffer $(0.4 \mathrm{M}$ Tris- $\mathrm{HCl})$ in 35 -min cycles, air dried, fixed in absolute ethanol for $10 \mathrm{~min}$, and stored for later analysis. For staining, the slides were covered with $100.0 \mu \mathrm{L}$ ethidium bromide $\left(20 \times 10^{-3} \mathrm{mg} / \mathrm{mL}\right)$ and a coverslip. The material was evaluated with a fluorescence microscope (Model L 2000A; Bioval, Brazil) at 40X magnification with a 420-490-nm excitation filter and a 520-nm barrier filter.

One hundred cells per treatment were visually analyzed, and comets were classified as follows: class 0 , undamaged cells without tails; class 1 , cells with tails smaller than the nucleoid diameter; class 2, cells with tail sizes between 1 and 2 times the nucleoid diameter; and class 3, cells with tails 2 times greater than the nucleoid diameter. Apoptotic cells, which exhibited totally fragmented nucleoids, were not counted (Kobayashi et al., 1995). The total score was calculated by summing the values resulting from multiplying the total cells observed in each lesion by the class value. The data were statistically analyzed using the ANOVA/Tukey test $(\mathrm{P}<0.05)$.

\section{ACF assay}

After euthanasia, the heart, lungs, liver, kidneys, and terminal portion of the intestine were collected for use in the ACF assay. To collect the organs, an incision was made on the ventral side of the animal along the midline from the pubic area to the xiphoid process. The abdominal muscles were folded laterally from the incisions in the proximal and distal portions. After locating the proximal colon, a ligature was made with a cotton thread. Distal to this ligature, the colon was removed from the proximal part to the rectum and flushed with $0.9 \%$ saline solution to remove the feces. After washing, the colon was opened longitudinally along the border of the mesenteric insertion and distended on Styrofoam plates, and the ends were fixed with pins. The plates were dipped in a vat containing a $10 \%$ buffered formalin solution for at least 24 hours.

During the analysis, each colon segment was stained with a $10 \%$ Giemsa solution for 
10 min and placed on a histological slide with the mucosa facing up. The analysis was performed using an optical microscope $\left(\mathrm{DBG}^{\circledR}\right.$, Brazil) at 10X magnification. The entire mucosa was examined to identify and count the number of ACF. ACF identification was based on the following criteria used by Bird (1987): I) a focus comprising a single crypt, with the aberrant crypt exhibiting a thick epithelial coating with an elliptical luminal opening and a size at least 2 times larger than that of the surrounding normal crypts; and II) a focus comprising 2 or more crypts in which the aberrant crypts form distinct blocks and occupy an area larger than the area occupied by an equivalent number of crypts of normal morphology, and in which no normal crypts separate the aberrant crypts within these foci.

In the statistical analysis of the ACF test data (total number of ACF, number of aberrant crypts per foci, and crypt/focus ratio), the different groups were compared using the ANOVA/Tukey test $(\mathrm{P}<0.05)$.

\section{Percent damage reduction (\%DR)}

The \%DR was calculated as per the following formula in accordance with Waters et al. (1990):

$\% \mathrm{DR}=\left[\frac{\text { Mean of positive control }- \text { Mean of associated group }}{\text { Mean of positive control }- \text { Mean of negative control }}\right] \times 100 \quad$ (Equation 1)

\section{RESULTS}

Although the animals were randomly assigned to groups, the weights differed significantly on experimental day $1(\mathrm{P}<0.05)$, with animals in the EDTA LPD and DMH LPD groups exhibiting higher mean bw. On experimental day 28 , after the depletion period, the animals supplemented with an NPD all exhibited similar weights that were distinct from those of animals supplemented with an LPD $(\mathrm{P}<0.05)$; the lowest mean was observed in the inulin-treated group. The analysis of the weight gain/loss during the depletion period (experimental day 1 to 28) demonstrated that the groups fed an NPD experienced similar weight gains. However, the Associate LPD group exhibited a trend toward weight loss. The groups supplemented with an LPD lost similar amounts of weight and exhibited differences when compared with the groups supplemented with an NPD. On experimental day 120, after the repletion period, the final weights and weight gain during the repletion period did not differ significantly among the experimental groups $(\mathrm{P}>0.05$; Table 1$)$.

The absolute weights of the lungs, liver, and kidneys and the relative weights of the heart, lungs, and kidneys did not differ $(\mathrm{P}>0.05)$. The mean absolute heart weight was significantly higher $(\mathrm{P}<0.05)$ in the EDTA LPD and Inulin LPD groups, and the mean relative liver weight was significantly lower $(\mathrm{P}<0.05)$ in the Associate NPD and Associate LPD groups (Table 2). 
W.B. Cantero et al.

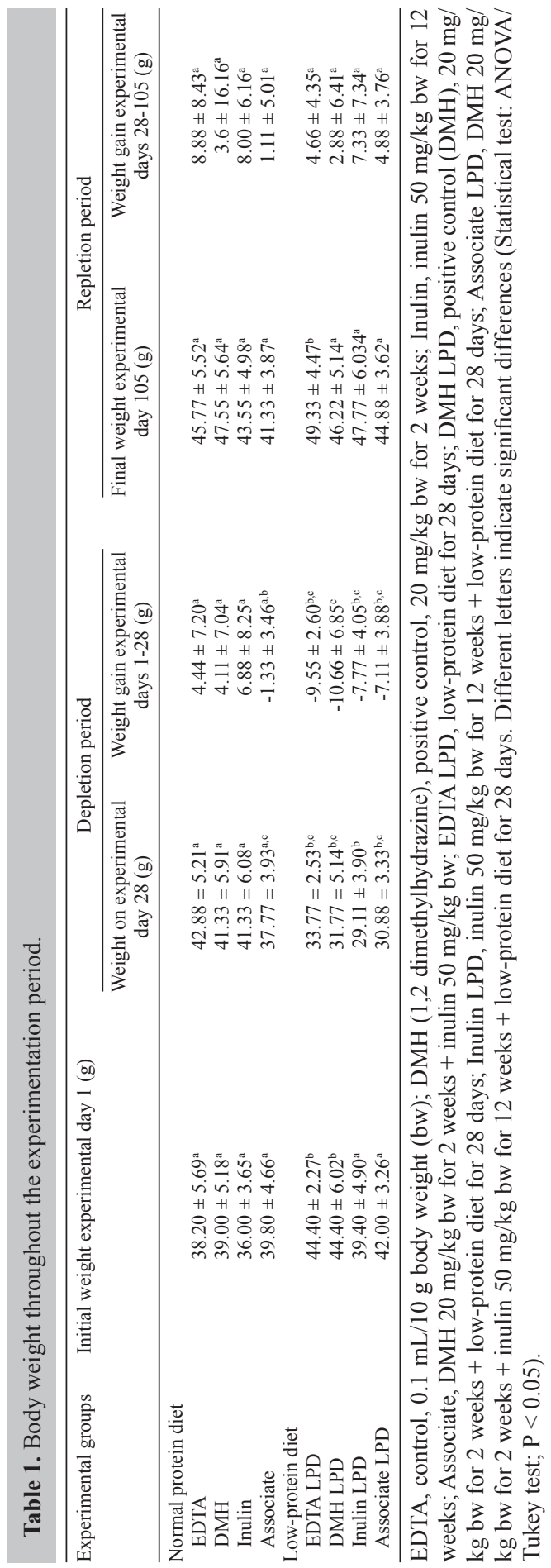


Table 2. Mean values \pm standard error of the absolute and relative weight of organs at the end of the experimental period.

\begin{tabular}{|c|c|c|c|c|}
\hline \multirow[t]{2}{*}{ Experimental groups } & \multicolumn{4}{|c|}{ Absolute weight of organs (g) } \\
\hline & Heart & Lungs & Liver & Kidneys \\
\hline \multicolumn{5}{|l|}{ Normal protein diet } \\
\hline EDTA & $0.2416 \pm 0.027^{\mathrm{a}}$ & $0.2429 \pm 0.610^{\mathrm{a}}$ & $2.4085 \pm 0.328^{\mathrm{a}}$ & $0.6047 \pm 0.101^{\mathrm{a}}$ \\
\hline DMH & $0.2116 \pm 0.217^{\mathrm{a}}$ & $0.2475 \pm 0.302^{\mathrm{a}}$ & $2.2787 \pm 0.000^{\mathrm{a}}$ & $0.6149 \pm 0.139^{\mathrm{a}}$ \\
\hline Inulin & $0.2643 \pm 0.058^{\mathrm{a}}$ & $0.2656 \pm 0.588^{\mathrm{a}}$ & $2.2219 \pm 0.491^{\mathrm{a}}$ & $0.7040 \pm 0.098^{\mathrm{a}}$ \\
\hline Associate & $0.2445 \pm 0.557^{\mathrm{a}}$ & $0.2390 \pm 0.299^{\mathrm{a}}$ & $1.7826 \pm 0.435^{\mathrm{a}}$ & $0.5852 \pm 0.103^{\mathrm{a}}$ \\
\hline \multicolumn{5}{|l|}{ Low-protein diet } \\
\hline EDTA LPD & $0.3063 \pm 0.828^{b}$ & $0.3037 \pm 0.400^{\mathrm{a}}$ & $2.2233 \pm 0.482^{\mathrm{a}}$ & $0.6739 \pm 0.097^{\mathrm{a}}$ \\
\hline DMH LPD & $0.3036 \pm 0.828^{\mathrm{a}}$ & $0.3509 \pm 0.151^{\mathrm{a}}$ & $2.2774 \pm 0.318^{\mathrm{a}}$ & $0.7126 \pm 0.153^{\mathrm{a}}$ \\
\hline Inulin LPD & $0.3055 \pm 0.812^{\mathrm{b}}$ & $0.3100 \pm 0.820^{\mathrm{a}}$ & $2.6419 \pm 0.381^{\mathrm{a}}$ & $0.6964 \pm 0.158^{\mathrm{a}}$ \\
\hline \multirow[t]{2}{*}{ Associate LPD } & $0.2468 \pm 0.892^{\mathrm{a}}$ & $0.2602 \pm 0.881^{\mathrm{a}}$ & $1.9009 \pm 0.324^{\mathrm{a}}$ & $0.6089 \pm 0.127^{\mathrm{a}}$ \\
\hline & \multicolumn{4}{|c|}{ Relative weight of organs (g) } \\
\hline \multicolumn{5}{|l|}{ Normal protein diet } \\
\hline EDTA & $0.0065 \pm 0.009^{\mathrm{a}}$ & $0.0067 \pm 0.022^{\mathrm{a}}$ & $0.0666 \pm 0.317^{\mathrm{b}}$ & $0.0167 \pm 0.040^{\mathrm{a}}$ \\
\hline DMH & $0.0055 \pm 0.010^{\mathrm{a}}$ & $0.0064 \pm 0.012^{\mathrm{a}}$ & $0.0548 \pm 0.062^{\mathrm{a}, \mathrm{b}}$ & $0.0159 \pm 0.028^{\mathrm{a}}$ \\
\hline Inulin & $0.0075 \pm 0.018^{\mathrm{a}}$ & $0.0074 \pm 0.016^{\mathrm{a}}$ & $0.0625 \pm 0.125^{\mathrm{a}, \mathrm{b}}$ & $0.0200 \pm 0.039^{\mathrm{a}}$ \\
\hline Associate & $0.0061 \pm 0.010^{\mathrm{a}}$ & $0.0060 \pm 0.010^{\mathrm{a}}$ & $0.0475 \pm 0.099^{\mathrm{a}}$ & $0.0146 \pm 0.024^{\mathrm{a}}$ \\
\hline \multicolumn{5}{|l|}{ Low-Protein Diet } \\
\hline EDTA LPD & $0.0068 \pm 0.019^{\mathrm{a}}$ & $0.0068 \pm 0.010^{\mathrm{a}}$ & $0.0503 \pm 0.126^{\mathrm{a}, \mathrm{b}}$ & $0.0151 \pm 0.025^{\mathrm{a}}$ \\
\hline DMH LPD & $0.0054 \pm 0.010^{\mathrm{a}}$ & $0.0077 \pm 0.028^{\mathrm{a}}$ & $0.0527 \pm 0.079^{\mathrm{a}, \mathrm{b}}$ & $0.0164 \pm 0.030^{\mathrm{a}}$ \\
\hline Inulin LPD & $0.0075 \pm 0.016^{\mathrm{a}}$ & $0.0077 \pm 0.023^{\mathrm{a}}$ & $0.0656 \pm 0.095^{\mathrm{b}}$ & $0.0174 \pm 0.043^{\mathrm{a}}$ \\
\hline Associate LPD & $0.0062 \pm 0.024^{\mathrm{a}}$ & $0.0065 \pm 0.024^{\mathrm{a}}$ & $0.0481 \pm 0.111^{\mathrm{a}}$ & $0.0154 \pm 0.041^{\mathrm{a}}$ \\
\hline
\end{tabular}

EDTA = control, $0.1 \mathrm{~mL} / 10 \mathrm{~g}$ bw (body weight); DMH (1,2 dimethylhydrazine) = positive control, $20 \mathrm{mg} / \mathrm{kg}$ bw for 2 weeks; Inulin $50 \mathrm{mg} / \mathrm{kg}$ bw for 12 weeks; Associate = DMH $20 \mathrm{mg} / \mathrm{kg}$ bw for 2 weeks + Inulin $50 \mathrm{mg} / \mathrm{kg}$ bw; EDTA LPD = low-protein diet for 28 days; DMH LPD = positive control (1,2 dimethylhydrazine), $20 \mathrm{mg} / \mathrm{kg}$ bw for 2 weeks + low-protein diet for 28 days; Inulin $=50 \mathrm{mg} / \mathrm{kg}$ bw for 12 weeks + low-protein diet for 28 days; Associate $\mathrm{LPD}=\mathrm{DMH} 20 \mathrm{mg} / \mathrm{kg}$ bw for 2 weeks + inulin $50 \mathrm{mg} / \mathrm{kg}$ bw for 12 weeks + low-protein diet for 28 days. Different letters indicate significant differences (Statistical Test: ANOVA/Tukey; $\mathrm{P}<0.05$ ).

In the comet assay, the frequencies of damaged cells in the groups supplemented with an NPD indicated that inulin was genotoxic but also exhibited anti-genotoxic activity, yielding a $\% \mathrm{DR}$ of $44.59 \%$. The administration of $\mathrm{DMH}$ and inulin significantly increased $(\mathrm{P}<0.05)$ the frequency of genomic lesions by 95.44 -fold and 53.33-fold, respectively (Table 3).

Table 3 also demonstrates that animals treated with an LPD (EDTA LPD, DMH LPD, Inulin LPD, and Associate LPD) exhibited similar frequencies of DNA lesions $(\mathrm{P}>0.05)$ and higher frequencies than the EDTA NPD group $(\mathrm{P}<0.05)$. Therefore, malnutrition (EDTA LPD) increased the DNA damage level by $63.88 \%$. Under conditions of malnutrition, the levels of damage caused by DMH (DMH LPD group) did not differ from those observed in the other groups subjected to the depletion period $(\mathrm{P}>0.05)$ but differed from those observed in the DMH NPD group. The Inulin LPD group exhibited the same level of DNA damage as did the other groups subjected to the LPD as well as a similar level of DNA damage as that observed in the Inulin NPD group. The Associate LPD group exhibited little damage reduction (3.89\%).

The negative control (EDTA NPD and EDTA LPD) and inulin (Inulin NPD and Inulin LPD) groups did not develop ACF and thus differed significantly from all other experimental groups in which ACF were observed. The DMH NPD and DMH LPD positive controls exhibited mean ACF numbers of $5.1 \pm 2.69$ and $8.1 \pm 1.90$, respectively, and an approximate increase in the ACF number of 1.59 -fold was observed as a function of the nutritional status. The \%DRs were approximately 47.05 and $59.25 \%$ for the Associate NPD and Associate LPD groups, respectively (Table 4). 
Table 3. Mean values \pm standard errors of the frequencies of damaged cells and the genotoxicity and antigenotoxicity damage class distributions in the peripheral blood of male mice fed a normal or low-protein diet as measured via comet assay.

\begin{tabular}{|c|c|c|c|c|c|c|}
\hline \multirow[t]{2}{*}{ Experimental groups } & \multirow[t]{2}{*}{ Damaged cells } & \multicolumn{4}{|c|}{ Damage class } & \multirow[t]{2}{*}{ Score } \\
\hline & & Class 0 & Class 1 & Class 2 & Class 3 & \\
\hline \multicolumn{7}{|l|}{ Normal Protein Diet } \\
\hline \multicolumn{7}{|l|}{ Genotoxicity } \\
\hline EDTA & $1.00 \pm 1.80^{\mathrm{a}}$ & $99.88 \pm 0.33$ & $0.11 \pm 9.00$ & $0.11 \pm 0.33$ & $0.00 \pm 0.00$ & $0.11 \pm 0.33^{\mathrm{d}}$ \\
\hline DMH & $95.44 \pm 4.79^{d}$ & $3.77 \pm 3.86$ & $14.33 \pm 8.86$ & $37.55 \pm 9.81$ & $43.55 \pm 5.63$ & $220.11 \pm 20.63^{\mathrm{a}}$ \\
\hline Inulin & $53.33 \pm 8.07^{b}$ & $46.66 \pm 8.07$ & $19.77 \pm 3.03$ & $19.11 \pm 4.83$ & $14.44 \pm 4.24$ & $101.33 \pm 17.64^{b}$ \\
\hline \multicolumn{7}{|l|}{ Antigenotoxicity } \\
\hline Associate & $71.22 \pm 5.95^{\mathrm{c}}$ & $26.11 \pm 6.93$ & $29.11 \pm 4.10$ & $20.66 \pm 5.19$ & $22.11 \pm 6.00$ & $139.66 \pm 18.80^{\mathrm{c}}$ \\
\hline \multicolumn{7}{|l|}{ Low-protein Diet } \\
\hline EDTA LPD & $63.88 \pm 6.58^{\mathrm{b}, \mathrm{c}}$ & $36 \pm 6.53$ & $26.44 \pm 5.91$ & $19.55 \pm 4.72$ & $17.88 \pm 4.19$ & $125.33 \pm 16.45^{b, c}$ \\
\hline DMH LPD & $58.22 \pm 6.94^{\mathrm{b}, \mathrm{c}}$ & $41.77 \pm 3.34$ & $23.11 \pm 7.80$ & $19.77 \pm 4.73$ & $15.33 \pm 4.47$ & $108.66 \pm 14.48^{b}$ \\
\hline Inulin LPD & $53.33 \pm 3.74^{\mathrm{b}}$ & $44.55 \pm 3.34$ & $19.55 \pm 4.06$ & $16.33 \pm 3.08$ & $20.11 \pm 2.08$ & $110.55 \pm 7.33^{\mathrm{b}}$ \\
\hline \multicolumn{7}{|l|}{ Antigenotoxicity } \\
\hline Associate LPD & $58.44 \pm 3.74^{\mathrm{b}, \mathrm{c}}$ & $41.77 \pm 3.34$ & $22.88 \pm 3.29$ & $18.44 \pm 2.35$ & $15.00 \pm 6.10$ & $108.88 \pm 6.71^{\mathrm{b}}$ \\
\hline
\end{tabular}

EDTA, control, $0.1 \mathrm{~mL} / 10 \mathrm{~g}$ body weight (bw); DMH (1,2 dimethylhydrazine), positive control, $20 \mathrm{mg} / \mathrm{kg}$ bw for 2 weeks; Inulin, inulin $50 \mathrm{mg} / \mathrm{kg}$ bw for 12 weeks; Associate, DMH $20 \mathrm{mg} / \mathrm{kg}$ bw for 2 weeks + inulin $50 \mathrm{mg} / \mathrm{kg}$ bw; EDTA LPD, low-protein diet for 28 days; DMH LPD, positive control (DMH), $20 \mathrm{mg} / \mathrm{kg}$ bw for 2 weeks + low-protein diet for 28 days; Inulin LPD, inulin $50 \mathrm{mg} / \mathrm{kg}$ bw for 12 weeks + low-protein diet for 28 days; Associate LPD, DMH $20 \mathrm{mg} / \mathrm{kg}$ bw for 2 weeks + inulin $50 \mathrm{mg} / \mathrm{kg}$ bw for 12 weeks + low-protein diet for 28 days. Different letters indicate significant differences (Statistical test: ANOVA/Tukey test; $\mathrm{P}<0.05$ ).

Table 4. Absolute and mean $[ \pm$ standard deviation (SD)] numbers, distributions, and percentages of damage reduction $(\% \mathrm{DR})$ of the aberrant crypt $(\mathrm{AC})$ foci $(\mathrm{ACF})$ in the colons of mice treated with inulin and fed a normal or low-protein diet.

\begin{tabular}{|c|c|c|c|c|c|c|c|c|c|}
\hline \multirow[t]{2}{*}{ Treatment } & \multicolumn{2}{|c|}{ Total ACF } & \multirow[t]{2}{*}{$\% \mathrm{DR}$} & \multirow[t]{2}{*}{ Total AC } & \multicolumn{4}{|c|}{ Absolute ACF values } & \multirow[t]{2}{*}{$\mathrm{AC} /$ Foci ratio } \\
\hline & $\begin{array}{l}\text { Absolute } \\
\text { values }\end{array}$ & $\begin{array}{c}\text { Mean } \\
\text { values } \pm \mathrm{SD}\end{array}$ & & & $1 \mathrm{AC} /$ Focus & $2 \mathrm{AC} /$ Focus & $3 \mathrm{AC} /$ Focus & $4 \mathrm{AC} /$ Focus & \\
\hline \multicolumn{10}{|l|}{ Normal protein diet } \\
\hline Control & 0.00 & $0^{\mathrm{a}}$ & - & 0.00 & 0.00 & 0.00 & 0.00 & 0.00 & 0.00 \\
\hline DMH & 51 & $5.1 \pm 2.69^{\mathrm{c}}$ & - & 82 & 21 & 20 & 9 & 1 & 1.60 \\
\hline Inulin & 0.00 & $0^{\mathrm{a}}$ & - & 0.00 & 0.00 & 0.00 & 0.00 & 0.00 & 0.00 \\
\hline \multicolumn{10}{|l|}{ Anticarcinogenicity } \\
\hline Associate & 27 & $2.7 \pm 1.06^{\mathrm{b}}$ & $47.05 \%$ & 50 & 13 & 4 & 5 & 3 & 1.85 \\
\hline \multicolumn{10}{|l|}{ Low-protein diet } \\
\hline Control LPD & 0.00 & $0^{\mathrm{a}}$ & - & 0.00 & 0.00 & 0.00 & 0.00 & 0.00 & 0.00 \\
\hline DMH LPD & 81 & $8.1 \pm 1.90^{\mathrm{d}}$ & - & 83 & 15 & 25 & 19 & 11 & 1.02 \\
\hline Inulin LPD & 0.00 & $0^{\mathrm{a}}$ & - & 0.00 & 0.00 & 0.00 & 0.00 & 0.00 & 0.00 \\
\hline \multicolumn{10}{|l|}{ Anticarcinogenicity } \\
\hline Associate LPD & 33 & $3.3 \pm 1.42^{\mathrm{c}}$ & $59.25 \%$ & 166 & 32 & 13 & 4 & 2 & 5.03 \\
\hline
\end{tabular}

Control, EDTA, $0.1 \mathrm{~mL} / 10 \mathrm{~g}$ body weight (bw); DMH (1,2 dimethylhydrazine), positive control, $20 \mathrm{mg} / \mathrm{kg}$ bw for 2 weeks; Inulin, inulin $50 \mathrm{mg} / \mathrm{kg}$ bw for 12 weeks; Associate, DMH $20 \mathrm{mg} / \mathrm{kg}$ bw for 2 weeks + inulin $50 \mathrm{mg} / \mathrm{kg}$ bw; EDTA LPD, low-protein diet for 28 days; DMH LPD, positive control (DMH), $20 \mathrm{mg} / \mathrm{kg}$ bw for 2 weeks + low-protein diet for 28 days; Inulin LPD, inulin $50 \mathrm{mg} / \mathrm{kg}$ bw for 12 weeks + low-protein diet for 28 days; Associate LPD, DMH $20 \mathrm{mg} / \mathrm{kg}$ bw for 2 weeks + inulin $50 \mathrm{mg} / \mathrm{kg}$ bw for 12 weeks + low-protein diet for 28 days. Different letters indicate significant differences (Statistical test: ANOVA/Tukey test; $\mathrm{P}<0.05$ ).

\section{DISCUSSION}

Reviews regarding the relationship between malnutrition and cancer are generally related to cancer cachexia, which is characterized by progressive weight loss, anorexia, asthe- 
nia, anemia, chronic nausea, and immunosuppression and is responsible for a large number of deaths in patients with advanced-stage cancer. Therefore, the malnutrition-cancer relationship is clinically distinct from the inversely proportional relationship between the degree of cachexia and the survival of cancer patients and also results in an unfavorable prognosis, reduction in suitable responses to therapies, and reduced quality of life (Argilés et al., 2006).

Few studies have investigated the effects of protein-calorie malnutrition and cancer development, and no studies have been published on inulin supplementation in chemical carcinogenesis models of deficiency states. Therefore, the present study is original and pioneering.

According to Monteiro (2003), malnutrition results from the chronic deficiency of 1 or more nutrients because adequate intake and biological calorie and protein utilization are necessary for body growth and maintenance (Hoffmann, 1995). Malnutrition is associated with the development of other conditions such as infection, immunosuppression, diabetes, hypertension, and obesity. Studies have also reported that malnutrition during critical and development-specific periods has long-lasting and/or persistent effects that can be defined as metabolic imprinting (Waterland and Gaza, 1999; Sawaya, 2006).

Female and male animals were mated in the present study, and the females had free access to water and a commercial diet (ad libitum) during the periods of pregnancy, lactation, and offspring development. The pups also had free access to water and food, thereby ensuring that the animals developed under optimum conditions of food availability and biological calorie and protein utilization. Subsequently, the animals treated with an LPD during the depletion period exhibited significant weight loss, which validated the experiment and indicated that the administration of an LPD for a 28-day period is sufficient to promote a deficiency status in animals, as previously reported by Teodósio et al. (1990) and Ferreira et al. (2005). Also of note, during the repletion period, (i.e., when the LPD was replaced by NPD), the depleted animals exhibited rapid weight gain and, at the end of the experiment, there was no longer evidence of animals with low weights and/or deficiency statuses. However, the relative liver weight displayed a trend toward weight loss in all animals except for the Inulin LPD group, with statistically significant decreases in the Associate NPD and Associate LPD groups.

When analyzing the frequencies of genomic lesions (comet assay) and premalignant lesions (ACF assay), malnutrition was found to increase the frequency of DNA damage by 63.88 -fold (EDTA LPD group). However, there was no correlation between this frequency and the levels of cancer biomarkers.

The relationship between malnutrition and DNA damage, which includes effects on chromosomal aberrations (Alu and Murthy, 1993) and increased frequencies of sister chromatid exchange (Betancourt et al., 1986), micronuclei (Ortiz et al, 1995), and comets (Cortés et al., 2001), has been previously reported. However, other studies have reported no correlations between malnutrition and increased genetic damage, whether genotoxic and/or mutagenic (Betancourt et al., 1995; Celik et al., 2012).

The following can be inferred to explain the increased genotoxicity observed in this experiment: I) the lack of nutrients causes the inadequate synthesis of proteins involved in the cell cycle and maintenance of DNA integrity and DNA repair; II) cells in malnourished bodies cannot sustain baseline DNA damage repair mechanisms; and III) malnutrition causes a lack of enzymes that prevent oxidative processes and free radical production (Webster et al., 1996; Cortés et al., 2001).

Studies have also reported that protein-calorie restriction decreases the activities of glutathione peroxidase, the antioxidant enzyme glutathione reductase, and glucose-6-phos- 
phate dehydrogenase in addition to reducing the serum levels of the important antioxidants vitamin E and glutathione (Cortés et al., 2001).

Epidemiological evidence also suggests that diets rich in vegetables and fruits are associated with a decreased incidence of cancer/genetic damage and that in the absence of the protective effects of these diets, the carcinogenic effects of xenobiotics may be exacerbated. Therefore, an unbalanced diet that fails to provide chemopreventive agents may indirectly contribute to a higher incidence of cancer initiation and development (Lutz, 1999), a fact that could also be considered when evaluating deficiency statuses in the context of protein-calorie malnutrition.

The absence of ACF in the EDTA LPD group, even after taking into account the high frequency of DNA damage detected by the comet assay, suggests that these lesions did not correlate directly with intestinal tumor initiation. This assertion was corroborated by the fact that DMH more effectively induced ACF in the DMH LPD group even without causing a significant increase in the comet frequency, given that this group developed 1.59-fold more foci than did the DMH NPD group.

$\mathrm{DMH}$ is an important carcinogen with a risk classification of $2 \mathrm{~A}$ according to the International Agency for Research on Cancer (Brasil, 2012). However, this compound is both a strong promoter and weak initiator of carcinogenesis. DMH is an indirect agent; in other words, it requires enzymes to convert it into an electrophilic species that will bind DNA (Newell and Heddle, 2004) and thus promote the formation of methyl group adducts, point mutations, and sister chromatid breakage (Newell and Heddle, 2004), which can then be evaluated by the alkaline $(\mathrm{pH}>13)$ version of the comet assay, as performed in this study. This assay detects direct damage, including single and double-strand breaks, alkali-labile sites, crosslinks, and excision repair sites, as well as indirect damage, including methylation and adduct lesions, which are alkali-labile and appear as simple breaks under alkali treatment (Vieira et al., 2014).

The administration of inulin to healthy (Inulin NPD) and malnourished animals (Inulin LPD) resulted in similar DNA damage frequencies, and neither of the 2 experimental groups developed intestinal cancer biomarkers. This genotoxic activity and non-induction of ACF following inulin treatment were previously reported by Mauro et al. (2013). According to those authors, such genotoxic damage is likely repaired, and therefore the tumor biomarker frequencies will not always correspond with the comet frequencies. This possibility of repair and non-correspondence was also reported by Oliveira et al. (2007).

In the antigenotoxicity test, inulin treatment induced $\% \mathrm{DR}$ of 25.64 and $3.87 \%$ in the NPD and LPD groups, respectively. This same inulin dose was previously tested by Mauro et al. (2003) in animals fed an NPD, and the corresponding \%DR were approximately 1.02, 9.97, -0.55 , and $3.92 \%$ for the pre-treatment, simultaneous, post-treatment, and pre+continuous protocols, respectively. Therefore, both studies suggest that inulin has no significant antigenotoxic activity. However, inulin exhibited considerably antimutagenic activity, with \%DR ranging from 77.46 to $141.75 \%$ at 48 hours after the last dose of DMH (Mauro et al., 2013). $\%$ DR values exceeding $100 \%$ also indicate the prevention of clastogenic and/or aneugenic basal damage. Similar reports were also observed with $\beta$-glucan saccharide supplementation in in vivo experiments and several treatments (Oliveira et al., 2014).

With respect to anticarcinogenicity, \%DR of approximately 47.05 and $59.25 \%$ were observed with inulin treatments in the NPD and LPD groups, respectively. In the study by Mauro et al. (2013), the \%DR were $69.12,87.56,55.78$, and $72.89 \%$ for the pre-treatment, simultaneous treatment, post-treatment, and pre+continuous protocols, respectively. These results, when combined with the micronucleus results, suggest that inulin can act as both a des- 
mutagenic and a bioantimutagenic agent; therefore, the present study took advantage of this knowledge and used a protocol that incorporated these 2 modes of action, thus explaining why inulin was administered before, during, and after the administration of DMH. Furthermore, inulin was part of the composition of both the NPD and LPD. There was a $12.2 \%$ difference between the 2 protocols (supplementation with NPD and LPD) in terms of the reduction in the ACF incidence. Therefore, the results suggest that inulin possesses the ability to prevent tumor development in malnourished animals.

Administration of the pro-carcinogenic agent DMH and repeated exposure of this agent to the intestinal mucosa induces lesions; cell proliferation is stimulated by $\mathrm{DMH}$, leading to aberrant crypt hyperplasia and mucosal hypertrophy and the subsequent development of ACF that can later develop into adenomas (Mauro et al., 2013). However, DMH must be metabolized in the liver prior to its conversion into a carcinogen. First, DMH is oxidized to azomethane and subsequently to azoxymethane, after which it is enzymatically hydroxylated to methylazoxymethanol (Lamont and O'Gorman, 1978).

Methylazoxymethanol has 3 fates: I) decomposition under body temperature into formaldehyde, water, nitrogen, and methyldiazonium, which is a potent alkylating agent (Nagasawa et al., 1972); II) alcohol dehydrogenase metabolism and conversion into methylazoxyformaldehyde in the liver, colon and, to a lesser degree, jejunum and ileum (Grab and Zedek, 1977 ); and III) conjugation with $\beta$-glucuronic acid in the liver followed by transport to the intestinal lumen, where the intestinal microflora will produce the enzyme $\beta$-glucuronidase, which in turn releases the carcinogenic metabolite of DMH (Lamont and O'Gorman, 1978).

To date, the metabolic capacity of malnourished animals has been thought to be less effective. Hence, it is possible to suggest that the higher \%DR associated with inulin in the malnourished group was due not only to the action of this fructooligosaccharide but also to a reduced capacity for DMH activation. Furthermore, protein-calorie malnutrition may be associated with intestinal villous atrophy as well as with an imbalance in the intestinal microbiota (Morais and Neto, 2003). This possibility would also induce a lower capacity for DMH activation in the intestine consequent to the reduced availability of $\beta$-glucuronidase, as this enzyme is produced by intestinal bacteria.

Another fact that should be mentioned is that inulin is preferentially metabolized by bifidobacteria in the intestines of humans and rodents. These bacteria produce little or no $\beta$-glucuronidase, thus reducing the possibility of releasing carcinogenic xenobiotics. Therefore, inulin intake exerts its anti-carcinogenic activity indirectly; in other words, it allows intestinal colonization by bifidobacteria, which compete with other bacteria that would increase the production of undesirable enzymes (Pool-Zobel et al., 2002; Mauro et al., 2013). Furthermore, bifidobacteria can produce lactic acid and reduce the $\mathrm{pH}$ of the fecal bolus and intestine. This reduction in $\mathrm{pH}$ acts as a bactericide against putrefactive bacteria and helps reduce the absorption of ammonia; both of these events are involved in increased intestinal carcinogenicity. It has also been suggested that these actions occurred preferentially in the group that received the NPD because of the balance in the intestinal flora.

Inulin exhibits the following anti-carcinogenic properties: I) apoptosis modulation via the production of short chain fatty acids, specifically butyrate, which are produced from bacterial inulin metabolism; II) intestinal mucosa protection and repair in the colon, which contributes to the reduction in intestinal diseases through the action of short-chain fatty acids (Cherbut, 2002); III) increased liver detoxification via the increased production of glutathione S-transferase and glucuronyltransferase, which are xenobiotic-metabolizing enzymes (Roland 
et al., 1996); IV) characteristics of dietary fiber (prebiotic) along with the capacity for adsorbing DNA damage-inducing agents; and V) the ability to form highly adsorptive microcrystals that facilitate xenobiotic elimination (Niness, 1999).

Therefore, malnutrition correlates with an increased frequency of genomic lesions but does not predispose affected individuals to colorectal cancer development. Inulin both possesses genotoxic activity, which requires further research, and exhibits low antigenotoxic activity. Moreover, inulin possesses the important ability to reduce intestinal carcinogenesis biomarkers in both malnourished and healthy animals. These data suggest that inulin has therapeutic potential and is a strong candidate among the functional foods used for cancer prevention in both properly nourished and malnourished individuals.

\section{ACKNOWLEDGMENTS}

Research funded by Fundação de Apoio ao Desenvolvimento do Ensino, Ciência e Tecnologia of the State of Mato Grosso do Sul (FUNDECT; Edital Chamada FUNDECT \#5/2011, PPP, Processo \#23/200.702/2012, Termo de Outorga \#0207/12), Fundação Araucária: Apoio ao Desenvolvimento Científico e Tecnológico do Paraná, and Pró-Reitoria de Pesquisa e Pós- Graduação (UniFil).

\section{REFERENCES}

Alu V and Murthy PB (1993). Chromosomal abnormalities in starved and marginally malnourished rats and in utero upon rehabilitation. Experientia 49: 258-262.

ANVISA. Agência Nacional de Vigilância Sanitária (2006). Alimentos Funcionais. Available at [http: www.anvisa.gov. br/alimentos/comissoes/tecno.htm]. Accessed August 05, 2014.

Argilés JM, Busquets S, Lopez-Soriano FJ and Figueras M (2006). Fisiopatología de la caquexia neoplásica. Nutr. Hosp. 21: 4-9.

Betancourt M, Balvanera P and Ortiz R (1986). Frequency of sister-chromatid exchange (SCE) in bone-marrow cells of severely malnourished animals during early life. Mutat. Res. 175: 29-31.

Betancourt M, Ortiz R, Gonzalez C, Perez P, et al. (1995). Assessment of DNA damage in leukocytes from infected and malnourished children by single cell gel electrophoresis/comet assay. Mutat. Res. 331: 65-77.

Bird RP (1987). Observation and quantification of aberrant crypts in the murine colon treated with a colon carcinogen: preliminary findings. Cancer Lett. 37: 147-151.

Brasil. Ministério da Saúde INdCJAGdSCGdAE (2012). Diretrizes para a Vigilância do Câncer Relacionado ao Trabalho. Available at [http://bvsms.saude.gov.br/bvs/publicacoes/inca/diretrizes_vigilancia_cancer_trabalho.pdf]. Accessed August 04, 2014.

Burns AJ and Rowland IR (2004). Antigenotoxicity of probiotics and prebiotics on faecal water-induced DNA damage in human colon adenocarcinoma cells. Mutat. Res. 551: 233-243.

Celik M, Sermatov K, Abuhandan M, Zeyrek D, et al. (2012). Oxidative status and DNA damage in chidren with marasmic malnutrition. J. Clin. Lab. Anal. 26: 161-166.

Cherbut C (2002). Inulin and oligofructose in the dietary fibre concept. Br. J. Nutr. 87 (Suppl 2): S159-S162.

Cortés E, González C, Betancourt M and Ortiz R (2001). Assessment of DNA damage in spleen, bone marrow, and peripheral blood from malnourished rats by single cell gel electrophoresis assay. Teratog. Carcinog. Mutagen. 21: 231-247.

Ferreira HS, Assunção ML, França AOS and Cardoso EPC (2005). Efetividade da "multimistura" como suplemento de dietas deficientes em vitaminas e/ou minerais na recuperação ponderal de ratos submetidos à desnutrição pós-natal. Rev. Nutr. 18: 63-74.

Grab DJ and Zedeck MS (1977). Organ-specific effects of the carcinogen methylazoxymethanol related to metabolism by nicotinamide adenine dinucleotide-dependent dehydrogenases. Cancer Res. 37: 4182-4189.

Hoffmann R (1995). Pobreza, insegurança alimentar e desnutrição no Brasil. Estud. Av. 9: 159-172.

Kaur N and Gupta AK (2002). Applications of inulin and oligofructose in health and nutrition. J. Biosci. 27: 703-714. 
Kobayashi H, Sugiyama C, Morikawa Y and Hayashi M (1995). Comparison between manual microscopic analysis and computerized image analysis in the single cell gel electrophoresis assay. MMS Commun. 3: 103-115.

LaMont JT and O'Gorman TA (1978). Experimental colon cancer. Gastroenterology 75: 1157-1169.

Lima JM and Navarro AC (2014). Sistema de vigilância alimentar e nutricional em crianças de Minas Gerais, Brasil: histórico, cobertura e estado nutricional. Rev. Bras. Obes. Nutr. Emag. 8: 55-64.

Lutz WK (1999). Carcinogens in the diet vs. overnutrition. Individual dietary habits, malnutrition, and genetic susceptibility modify carcinogenic potency and cancer risk. Mutat. Res. 443: 251-258.

Mauro MO, Monreal MT, Silva MT, Pesarini JR, et al. (2013). Evaluation of the antimutagenic and anticarcinogenic effects of inulin in vivo. Genet. Mol. Res. 12: 2281-2293.

Monteiro CA (2003). A dimensão da pobreza, da fome e da desnutrição no Brasil. Estud. Av. 17: 7-20.

Morais MB and Neto UF (2003). Enteropatia ambiental. Estud. Av. 48: 137-148.

Nagasawa HT, Shirota FN and Matsumoto H (1972). Decomposition of methylazoxymethanol, the aglycone of cycasin, in H2O. Nature 236: 234-235.

Newell LE and Heddle JA (2004). The potent colon carcinogen, 1,2-dimethylhydrazine induces mutations primarily in the colon. Mutat. Res. 564: 1-7.

Niness KR (1999). Inulin and oligofructose: what are they? J. Nutr. 129: 1402S-1406S.

Oliveira RJ, Matuo R, da Silva AF, Matiazi HJ, et al. (2007). Protective effect of $\beta$-glucan extracted from Saccharomyces cerevisiae, against DNA damage and cytotoxicity in wild-type (k1) and repair-deficient (xrs5) CHO cells. Toxicol. In Vitro 21: 41-52.

Oliveira RJ, Pesarini JR, Sparca Salles MJ, Nakamura Kanno TY, et al. (2014). Effects of $\beta$-glucan polysaccharide revealed by the dominant lethal assay and micronucleus assays, and reproductive performance of male mice exposed to cyclophosphamide. Genet. Mol. Biol. 37: 111-119.

Ortiz R, Cortes E, Gonzalez C, Perez L, et al. (1995). Micronucleus frequency in spleen lymphocytes from severely malnourished rats during lactation. Environ. Mol. Mutagen. 26: 55-59.

Pesarini JR, Zaninetti PT, Mauro MO, Carreira CM, et al. (2013). Antimutagenic and anticarcinogenic effects of wheat bran in vivo. Genet. Mol. Res. 12: 1646-1659.

Pool-Zobel B, van Loo J, Rowland I and Roberfroid MB (2002). Experimental evidences on the potential of prebiotic fructans to reduce the risk of colon cancer. Br. J. Nutr. 87 (Supp1 2): S273-S281.

Ribeiro CCC, Silva MCB, Machado CMP and Ribeiro MRC (2014). A gravidade da cárie está associada à desnutrição protéico-calórica em pré-escolares? Ciênc. Saúde Coletiva 19: 957-965.

Roberfroid MB (2002). Functional foods: concepts and application to inulin and oligofructose. Br. J. Nutr. 87 (Suppl 2): S139-S143.

Roland N, Rabot S and Nugon-Baudon L (1996). Modulation of the biological effects of glucosinolates by inulin and oat fibre in gnotobiotic rats inoculated with a human whole faecal flora. Food Chem. Toxicol. 34: 671-677.

Sawaya AL (2006). Desnutrição: conseqüências em longo prazo e efeitos da recuperação nutricional. Estud. Av. 20: 147158.

Silva RCP, Perez MG, Zaninetti PT and Escobar DS (2011). Efeitos da restrição alimentar, pelo método de Meal Feeding, e da suplementação de semente de linhaça (Linum usitatissimum) no câncer de colorretal de camundongos Swiss. Terra e Cultura 53: 51-65.

Singh NP, McCoy MT, Tice RR and Schneider EL (1988). A simple technique for quantitation of low levels of DNA damage in individual cells. Exp. Cell Res. 175: 184-191.

Teodósio NR, Lago ES, Romani SA and Guedes RC (1990). A regional basic diet from northeast Brazil as a dietary model of experimental malnutrition. Arch. Latinoam. Nutr. 40: 533-547.

Vieira MHC, Oliveira RJ, Eça LPM and Pereira ISO (2014). Therapeutic potential of mesenchymal stem cells to treat Achilles tendon injuries. Genet. Mol. Res. 13: 10434-10449.

Waterland RA and Garza C (1999). Potential mechanisms of metabolic imprinting that lead to chronic disease. Am. J. Clin. Nutr. 69: 179-197.

Waters MD, Brady AL, Stack HF and Brockman HE (1990). Antimutagenicity profiles for some model compounds. Mutat. Res. 238: 57-85.

Webster RP, Gawde MD and Bhattacharya RK (1996). Modulation of carcinogen-induced DNA damage and repair enzyme activity by dietary riboflavin. Cancer Lett. 98: 129-135. 